\title{
Assessment of Change in Microbiology and Antibiotic Sensitivity of Deep Neck Infection Over 10 Years
}

\author{
Ju Hyun Yun, Soo Jin Kim, Han Su Kim, and Soo Yeon Jung ${ }^{(D)}$ \\ Department of Otorhinolaryngology-Head and Neck Surgery, College of Medicine, Ewha Womans University, Seoul, Korea
}

심경부 감염 환자의 세균 동정 및 항생제 감수성의 변화

윤주현 · 김수진 · 김한수 · 정수연

이화여자대학교 의과대학 이비인후-두경부외과학교실

\author{
Received March 9, 2020 \\ Revised May 20, 2020 \\ Accepted July 6, 2020 \\ Address for correspondence \\ Soo Yeon Jung, MD, PhD \\ Department of Otorhinolaryngology- \\ Head and Neck Surgery, \\ College of Medicine, \\ Ewha Womans University, \\ 1071 Anyangcheon-ro, \\ Yangcheon-gu, Seoul 07985, Korea \\ Tel $+82-2-2650-5832$ \\ Fax $+82-2-2648-5604$ \\ E-mail mdjungsy@ewha.ac.kr
}

Background and Objectives Treatment using systemic antibiotic administration and surgical drainage has been the common treatment modality for deep neck infection. This study compared the changing pattern of isolated pathogens to recommend the best empirical antibiotics for deep neck infection.

Subjects and Method Reviewed retrospectively were medical charts of 131 patients who, confirmed with deep neck infection, underwent surgical drainage for pus cultures at Ewha Womans University Medical Center between January, 2009 and July, 2019. We analyzed the changing pattern of isolated pathogens and antibiotic susceptibility tests using their pus cultures. Results Streptococcus viridans was the most commonly isolated organism (35.1\%), followed by Klebsiella pneumonia (13.7\%) and Staphylococcus aureus (4.6\%). The isolation rate of Streptococcus viridans increased in the recent 10 years $[p=0.016$, odds ratio $(\mathrm{OR})=3.417]$. Antibiotic susceptibility tests showed that all pathogens were resistant to ampicillin, but susceptible to ampicillin/sulbactam and cephalosporin. The isolation rate of clindamycin resistant pathogens was increased with statistical significance $(p=0.020, \mathrm{OR}=8.076)$.

Conclusion Antibiotics effective against both Streptococcus viridans and Klebsiella pneumonia should be used as the first-line of treatment for deep neck infection. Ampicillin/sulbactam or amoxicillin/clavulanic acid were sufficient to treat deep neck infection empirically regardless of age or underlying diseases.

Korean J Otorhinolaryngol-Head Neck Surg 2021;64(5):327-35

Key Words Antibiotics · Infection · Microbiology $\cdot$ Neck.

\section{서 론}

심경부 감염은 심부 경부 근막에 의해 경계지어지는 잠재 적 공간에 발생하는 감염을 일컫는다. ${ }^{1)}$ 과거에 주된 원인으로 알려져 있던 인두편도염 등의 상기도 감염과 함께 최근 증가 하고 있는 치성 감염이 심경부 감염의 주원인으로 생각되고 있다. ${ }^{2}$ 항생제 치료의 발달 및 구강 위생의 향상으로 심경부

This is an Open Access article distributed under the terms of the Creative Commons Attribution Non-Commercial License (https://creativecommons.org/licenses/by-nc/4.0) which permits unrestricted non-commercial use, distribution, and reproduction in any medium, provided the original work is properly cited.
감염의 발병률이 감소하고 있는 추세이지만, 빠른 시간 내에 적절한 치료가 선행되지 않는다면 상기도 폐쇄, 하행성 종격 동염, 농흥(pleural empyema), 심낭염, 경정맥 혈전증, 패혈증, 경동맥 가성동맥류 혹은 경동맥 파열 등의 생명을 위협하는 합병증을 유발할 수 있다. ${ }^{1,3)}$ 심경부 감염의 치료로는 크게 항 생제 치료와 절개배농술이 있다. 호기성 및 혐기성 균을 치료 하는 경험적 항생제를 투여한 후 세균배양검사에 따라 필요 한 경우 감수성 있는 항생제로 교체해 주어야 하며, 항생제 투여 48시간이 지난 후에도 증상의 호전이 없거나 심각한 합 병증이 동반된 경우, 두 개 이상의 경부 공간을 침범했을 때 
농양의 크기가 $3 \mathrm{~cm}$ 이상인 경우에는 절개배농술을 고려해 볼 수 있다. ${ }^{4}$ 교과서에서는 심경부 감염의 경험적 항생제로 amoxicillin-clavulanate 병합요법이나 $\beta$-lactamase-resistant 항생제와 함께 혐기성 균에 효과적인 clindamycin 혹은 metronidazole을 투여하도록 소개하고 있다. 하지만 최근 항 생제 내성 세균이 증가하면서 기존에 사용하고 있는 경험적 항생제가 심경부 감염 치료에 대해 적절한 지에 대한 의구심 이 생긴다. 이에 본 연구에서는 지난 10 여 년간 심경부 감염 으로 절개배농술을 시행받은 환자들을 경과에 따라 경증, 중 증으로 분류하고, 세균배양검사 및 항생제 감수성 결과의 변 화 양상을 비교·분석하여 심경부 감염 환자에서 사용할 수 있는 가장 적절한 경험적 항생제를 추천하고자 하는 목적으 로 시행하였다.

\section{대상 및 방법}

2009년 1월 2019년 7월까지 본원 이비인후과에 입원하여 심경부 감염 진단 하 절개배농술을 시행한 환자들의 의무기 록을 검토하는 방식으로 후향적 연구를 진행하였다. 본 연구 는 본원 기관생명윤리심의위원회의 승인을 득하여 진행하였 다(IRB no. EUMC 2020-02-041). 경부 전산화단층촬영에서 심경부에 농양이 형성되어 있는 경우 절개배농술을 시행하고, 배농된 고름으로 세균배양검사 및 항생제 감수성 검사를 진 행한 환자를 대상으로 하였다. 편도 주위 농양, 얕은 감염 혹 은 농양이 형성되지 않은 연조직염 등은 제외하고 기준에 부 합하는 총 131 명의 환자를 연구 대상에 포함하였다.

환자들은 발열, 경부 통증, 종창, 연하통, 개구장애 등을 주 소로 이대목동병원 이비인후과 외래 혹은 응급실로 내원하 였으며, 신체검사 및 후두 내시경 검사상 심경부 감염 의심되 어 경부 전산화단층촬영을 시행하였다. 경부 전산화단층촬영 에서 심경부에 농양이 형성되어 있는 것을 확인한 후 위치에 따라 구강 내 접근법 혹은 외부 접근법으로 절개배농술을 시행하였다. 또한 입원 즉시 호기성 세균뿐만 아니라 혐기성 세균을 포함하는 경험적 항생제를 사용하였다.

연구 대상 환자들 중 입원기간이 7일 이상이거나 수술을 2 회 이상 시행한 경우, 치료 도중 사망한 경우, 중환자실에 입실해서 치료받은 적이 있는 경우를 중증으로, 상기 조건에 모두 포함되지 않은 환자들은 경증으로 분류하였다. 연구 대 상 환자들의 인구학적 특성을 확인하기 위해 성별, 나이, 기저 질환 및 생활습관에 대해 비교· 분석하였다. 생활습관은 음주 및 흡연력을 분석하였으며, 주 2 회 이상 음주하면서 1 회 평균 음주량이 남성은 7잔 이상, 여성은 5잔 이상인 경우에 고위험 음주군으로 나누었다. 침범 부위는 인두곁공간, 악하공간, 설
하공간, 이하공간, 인두뒤공간, 전경부공간(anterior cervical space), 후경부공간(posterior cervical space), 저작근공간 (masticator space), 내장공간(visceral space) 및 목동맥공간 (carotid space)로 분류하였다. 또한 세균 배양 검사 결과 동 정된 세균을 호기성, 혐기성, 그람 염색 여부에 따라 분석하 였으며, 10 여 년 동안 동정된 세균의 변화 양상을 확인하고, 주로 동정된 세균들의 항생제 감수성 결과를 비교하였다. SPSS(ver. 22.0; IBM Corp., Armonk, NY, USA) 통계 프로 그램을 사용하여 카이제곱 검정 및 Fisher의 정확한 검정을 시행하여 분석하였다.

\section{결 과}

131 명의 환자 중 여성은 38명(29.0\%), 남자는 93명(71.0\%)이 었으며 연령분포는 3 개월부터 86 세까지였다. 기저질환으로는 당뇨(26.7\%), 고혈압(23.7\%)이 가장 흔하였고, 이어서 심혈관 질환(7.6\%), 암(5.4\%), 간경화(3.8\%)가 뒤따랐다. 경증 및 중증 환자군에서 성별 분포의 유의미한 차이는 없었다 $(p=0.883)$. 당뇨 $(p<0.001)$ 를 가진 환자의 비율이 중증 환자군에서 유의 미하게 높게 나타났으며, 당뇨를 가진 환자가 심경부 감염에 걸렸을 경우 그렇지 않은 환자에 비해 심각한 경과를 보일 확 률이 18.7 배 높았다. 당뇨 외 다른 기저질환은 경증과 중증 환자군에서 통계학적으로 유의미한 차이는 없었다. 흡연자의 경우 비흡연자에 비해 중증 환자군의 비율이 유의미하게 높 게 나타났다 $(p=0.034)$ (Table 1). 10여 년 동안 당뇨 $(p=0.644)$ 를 가지거나 흡연( $p=0.365)$, 고위험 음주 $(p=0.253)$ 를 하는 환 자의 비율의 변화 양상을 살펴보았을 때, 유의미한 변화를 보 이지 않았다(Fig. 1). 경부 전산화단층촬영을 분석한 결과 가 장 흔한 심경부 감염 침범 부위는 인두곁공간(42.7\%)이었고, 악하공간(20.6\%), 설하공간(14.5\%), 인두뒤공간(10.7\%)이 뒤 를 이었다. 악하공간 $(p=0.030)$ 에 침범된 확률이 중증 환자군 에서 통계학적으로 유의미하게 높게 나타났으나, 그 외 침범 부위는 질병의 중증도에 따른 유의미한 차이를 보이지 않았 다(Table 2).

세균배양검사 결과 Streptococcus viridans(35.1\%)가 가장 높은 빈도로 동정되었고, 그 뒤를 이어 Klebsiella pneumonia (13.7\%), Staphylococcus aureus(4.6\%)가 동정되었다. 세균이 동정되지 않은 경우는 $35.1 \%$ 에 달했다. 경증과 중증 환자군 에서의 세균배양검사 결과를 비교해 보면 전체 환자군에서와 유사하게 Streptococcus viridans(34.6\%, 36.5\%), Klebsiella pneumonia $(16.7 \%, 9.6 \%)$ 가 가장 흔하게 동정되었으며, 심경부 감염 침범 부위에 따른 세균배양검사 결과에서도 동일한 소 견을 보였다(Tables 3 and 4). 남성, 여성에서 모두 전체 환자 
Table 1. Demographics of patients presenting with deep neck infections $(n=131)$

\begin{tabular}{lcccc}
\hline \multirow{2}{*}{$\begin{array}{c}\text { Patient } \\
\text { demographics }\end{array}$} & \multicolumn{4}{c}{ No. of patients (\%) } \\
\cline { 2 - 5 } $\begin{array}{c}\text { Sex } \\
\text { Female }\end{array}$ & $\begin{array}{c}\text { Severe } \\
\text { case }\end{array}$ & $\begin{array}{c}\text { Mild } \\
\text { case }\end{array}$ & p-value \\
$\quad 38(29.0)$ & $23(29.5)$ & $15(28.3)$ & 0.883 \\
Male & $93(71.0)$ & $55(70.5)$ & $38(71.7)$ & \\
Underlying disease & & & & \\
Diabetic mellitus & $35(26.7)$ & $33(42.3)$ & $2(3.8)$ & $<0.001$ \\
Hypertension & $31(23.7)$ & $23(29.5)$ & $8(15.1)$ & 0.057 \\
Cardio-vascular & $10(7.6)$ & $7(9.0)$ & $3(5.7)$ & 0.739 \\
$\quad$ disease & & & & \\
Cancer & $7(5.4)$ & $4(5.1)$ & $3(5.7)$ & 1.000 \\
$\quad$ Liver cirrhosis & $5(3.8)$ & $5(6.4)$ & $0(0)$ & 0.081 \\
Thyroid disease & $3(2.3)$ & $1(1.3)$ & $2(3.8)$ & 0.565 \\
Chronic renal disease & $2(1.5)$ & $2(2.6)$ & $0(0)$ & 0.520 \\
Life style & & & & \\
High-risk alcohol & $37(28.2)$ & $22(28.2)$ & $15(28.3)$ & 0.990 \\
$\quad$ drinking & & & & \\
Smoking & $54(41.2)$ & $38(48.7)$ & $16(30.2)$ & 0.034 \\
\hline
\end{tabular}

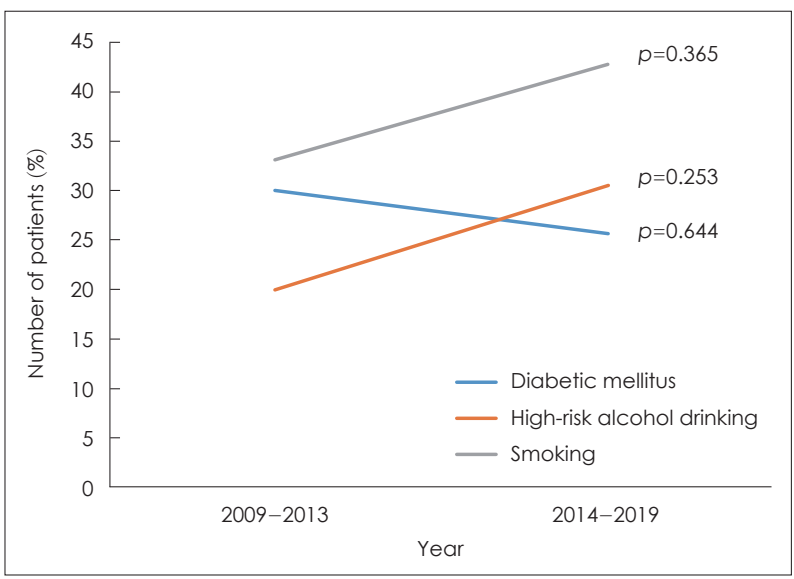

Fig. 1. Changing trends of number of patients with diabetic mellitus, high-risk alcohol drinking, or smoking history during 10 years. The number of patients with diabetic mellitus $(p=0.644)$ was decreased in the recent 10 years, but it was not statistically significant. The change of number of patients with high-risk alcohol drinking $(p=0.253)$ and smoking history was also statistically insignificant.

군에서의 세균배양검사 결과와 동일하게 Streptococcus viri$\operatorname{dans}(33.3 \%, 39.5 \%)$ 가 가장 높은 빈도로 동정되었으며, 남성 에서는 Klebsiella pneumonia(16.1\%), 여성에서는 Klebsiella pneumonia(7.9\%), Staphylococcus aureus(7.9\%)가 다음으로 흔하게 동정되었다. 세균배양검사 결과 성별에 따라 각 세균 의 동정률의 유의미한 차이는 없었다. 소아의 세균배양검사 결과 Staphylococcus aureus(33.3\%)가 가장 흔하게 동정되었 고, 그 뒤를 이어 Streptococcus viridans(16.7\%), Streptococcus pyogens $(16.7 \%)$ 가 동정되었으며, 성인에서 두 번째로 흔
Table 2. Distribution of the involved space of deep neck infections $(n=131)$

\begin{tabular}{lcccc}
\hline \multirow{2}{*}{ Space } & \multicolumn{4}{c}{ No. of patients (\%) } \\
\cline { 2 - 5 } & Total & $\begin{array}{c}\text { Severe } \\
\text { case }\end{array}$ & $\begin{array}{c}\text { Mild } \\
\text { case }\end{array}$ & p-value \\
\hline Parapharyngeal space & $56(42.7)$ & $29(37.2)$ & $27(50.9)$ & 0.118 \\
Submandibular space & $27(20.6)$ & $21(26.9)$ & $6(11.3)$ & 0.030 \\
Sublingual space & $19(14.5)$ & $9(11.5)$ & $10(18.9)$ & 0.242 \\
Retropharyngeal space & $14(10.7)$ & $11(14.1)$ & $3(5.7)$ & 0.125 \\
Posterior cervical space & $11(8.4)$ & $8(10.3)$ & $3(5.7)$ & 0.524 \\
Anterior cervical space & $9(6.9)$ & $7(9.0)$ & $2(3.8)$ & 0.311 \\
Parotid space & $6(4.6)$ & $6(7.7)$ & $0(0)$ & 0.081 \\
Masticator space & $5(3.8)$ & $4(5.1)$ & $1(1.9)$ & 0.648 \\
Visceral space & $2(1.5)$ & $1(1.3)$ & $1(1.9)$ & 1.000 \\
Carotid space & $2(1.5)$ & $2(2.6)$ & $0(0)$ & 0.515 \\
\hline
\end{tabular}

하게 동정되었던 Klebsiella pneumonia는 소아에서는 동정 되지 않았다(Table 3). 흡연자와 비흡연자 사이에 세균배양검 사 결과의 통계학적으로 유의미한 차이를 보이지 않았으며, 고위험 음주자와 그렇지 않은 환자 사이에서 Escherichia coli $(p=0.021)$ 의 동정률이 유의미한 차이를 보였으나 그 외 세균 에서는 음주 여부에 따른 동정률의 차이는 없었다(Table 5). Klebsiella pneumonia의 경우 당뇨 환자에서 당뇨에 이환되 지 않은 환자에 비해 동정률이 3.364배 높았다 $(p=0.023)$. 그 외 다른 세균의 동정률에서는 당뇨 여부에 따른 유의미한 차 이를 보이지 않았다(Table 6).

2009 2013년과 2014 2019년 두 기간으로 나누어 10여 년 동안 동정된 세균의 변화 양상을 살펴보았다. 그람 양성 세균 $[p=0.007$, odds ratio(OR) $=3.487)$ 및 혐기성 세균 $(p=0.684$, $\mathrm{OR}=2.495)$ 은 최근 들어 동정률이 증가하는 양상을 보이는 반면, 그람 음성 세균 $(p=0.178, \mathrm{OR}=0.518)$ 은 동정률이 감소 하는 형태를 보이고 있다(Fig. 2A). Streptococcus viridans $(p=0.016, \mathrm{OR}=3.417)$ 는 같은 기간 동안 동정률이 통계적으로 유의미하게 증가하였으며, Klebsiella pneumonia( $p=0.372$, $\mathrm{OR}=0.578$ )는 감소하는 양상이나 유의미한 차이는 없었다 (Fig. 2B and C).

세균별로 항생제 감수성 결과를 비교해 보면 가장 흔하게 동정된 Streptococcus viridans의 경우 clindamycin, erythromycin에서 각각 $43.4 \%, 47.8 \%$ 의 내성률을 보였으나 ampicillin, ceftriaxone 계열의 항생제에는 모두 감수성이 있었다. Klebsiella pneumonia에서는 2건을 제외한 나머지 16건 (88.9\%)에서 ampicillin에 내성을 보였고, amoxicillin/clavulanic acid, cefoxitin에 내성을 보이는 사례가 각각 1건씩 보고되었다. Staphylococcus aureus가 동정된 6건에서 모두 penicillin에 내성을 보였다. Clindamycin 및 erythromycin 에 내성을 보인 건수도 $50 \%$ 였으며, 모두 소아 환자에서 동정 
Table 3. Microbiology results of patients with deep neck infections according to demographics

\begin{tabular}{|c|c|c|c|c|c|c|c|c|c|c|}
\hline \multirow{3}{*}{ Organism } & \multicolumn{10}{|c|}{ No. of patients (\%) } \\
\hline & \multirow[b]{2}{*}{ Total } & \multicolumn{3}{|c|}{ Severity } & \multicolumn{3}{|c|}{ Sex } & \multicolumn{3}{|c|}{ Age } \\
\hline & & $\begin{array}{c}\text { Severe } \\
\text { case }\end{array}$ & $\begin{array}{l}\text { Mild } \\
\text { case } \\
\end{array}$ & p-value & Female & Male & p-value & Adult & Pediatric & p-value \\
\hline No growth bacteria & $46(35.1)$ & $29(37.2)$ & $17(32.7)$ & 0.548 & $12(31.6)$ & $34(36.6)$ & 0.588 & $42(35.3)$ & $4(33.3)$ & 1.000 \\
\hline \multicolumn{11}{|l|}{ Aerobes } \\
\hline \multicolumn{11}{|l|}{ Gram-positve bacteria } \\
\hline Streptococcus viridans & $46(35.1)$ & $27(34.6)$ & $19(36.5)$ & 0.885 & $15(39.5)$ & 31 (33.3) & 0.504 & $44(37.0)$ & $2(16.7)$ & 0.213 \\
\hline Staphylococcus aureus & $6(4.6)$ & $2(2.6)$ & $4(7.7)$ & 0.221 & $3(7.9)$ & $3(3.2)$ & 0.356 & $2(1.7)$ & $4(33.3)$ & 0.001 \\
\hline Streptococcus pyogens & $5(3.8)$ & $1(1.3)$ & $4(7.7)$ & 0.157 & $2(5.3)$ & $3(3.2)$ & 0.627 & $3(2.5)$ & $2(16.7)$ & 0.066 \\
\hline Streptococcus, group F & $1(0.8)$ & $1(1.3)$ & $0(0.0)$ & 1.000 & $1(2.6)$ & $0(0.0)$ & 0.290 & $1(0.8)$ & $0(0.0)$ & 1.000 \\
\hline Staphylococcus epidermis & $1(0.8)$ & $1(1.3)$ & $0(0.0)$ & 1.000 & $0(0.0)$ & $1(1.1)$ & 1.000 & $1(0.8)$ & $0(0.0)$ & 1.000 \\
\hline \multicolumn{11}{|l|}{ Gram-negative bacteria } \\
\hline Klebsiella pneumoniae & $18(13.7)$ & $13(16.7)$ & $5(9.6)$ & 0.238 & $3(7.9)$ & $15(16.1)$ & 0.214 & $18(15.1)$ & $0(0.0)$ & 0.371 \\
\hline Escherichia coli & $3(2.3)$ & $3(3.8)$ & $0(0.0)$ & 0.272 & $0(0.0)$ & $3(3.2)$ & 0.556 & $3(2.5)$ & $0(0.0)$ & 1.000 \\
\hline Enterobacter sp. & $2(1.5)$ & $1(1.3)$ & $1(1.9)$ & 1.000 & $1(2.6)$ & $1(1.1)$ & 0.498 & $2(1.7)$ & $0(0.0)$ & 1.000 \\
\hline Neisseria sp. & $1(0.8)$ & $1(1.3)$ & $0(0.0)$ & 1.000 & $1(2.6)$ & $0(0.0)$ & 0.290 & $1(0.8)$ & $0(0.0)$ & 1.000 \\
\hline Acinetobacter & $1(0.8)$ & $1(1.3)$ & $0(0.0)$ & 1.000 & $0(0.0)$ & $1(1.1)$ & 1.000 & $1(0.8)$ & $0(0.0)$ & 1.000 \\
\hline \multicolumn{11}{|l|}{ Anaerobes } \\
\hline \multicolumn{11}{|l|}{ Gram-positive bacteria } \\
\hline Peptostreptococcus sp. & $4(3.1)$ & $1(1.3)$ & $3(5.8)$ & 0.303 & $0(0.0)$ & $4(4.3)$ & 0.322 & $4(3.4)$ & $0(0.0)$ & 1.000 \\
\hline Lactobacillus & $1(0.8)$ & $1(1.3)$ & $0(0.0)$ & 1.000 & $1(2.6)$ & $0(0.0)$ & 0.290 & $1(0.8)$ & $0(0.0)$ & 1.000 \\
\hline \multicolumn{11}{|l|}{ Gram-negative bacteria } \\
\hline Prevotella sp. & $3(2.3)$ & $3(3.8)$ & $0(0.0)$ & 0.272 & $2(5.3)$ & $1(1.1)$ & 0.202 & $3(2.5)$ & $0(0.0)$ & 1.000 \\
\hline Citrobacter & $1(0.8)$ & $1(1.3)$ & $0(0.0)$ & 1.000 & $0(0.0)$ & $1(1.1)$ & 1.000 & $1(0.8)$ & $0(0.0)$ & 1.000 \\
\hline
\end{tabular}

sp.: species

된 경우였다. Streptococcus pyogens는 clindamycin과 gentamicin에 내성을 보이는 건수가 각각 1건씩 보고되었다 (Fig. 3).

Ampicillin은 모든 동정된 세균에 대한 저항성이 비교적 높은 반면, ampicillin/sulbactam은 감수성이 높게 나타났다. Erythromycin과 clindamycin도 저항성이 비교적 높은 편이 었으나 cephalosporin 계열 항생제는 모든 동정된 세균에 대 해 민감도가 높은 것으로 확인되었다(Fig. 4).

10 여 년 동안 동정된 세균의 2세대 cephalosporin( $p=1.000)$, 3 세대 cephalosporin $(p=1.000)$, clindamycin $(p=0.020)$, amoxicillin/clavulanic $\operatorname{acid}(p=1.000)$ 및 ampicillin/sulbactam ( $p=1.000)$ 에 대한 내성률이 모두 증가하는 양상을 보인다. 그 러나 clindamycin 내성 세균만이 통계학적으로 유의미하게 동정률이 8.076배 증가하였다(Fig. 5A). Streptococcus viridans와 Klebsiella pneumonia 각각의 항생제에 대한 내성률 의 변화는 통계학적으로 유의미한 차이를 보이지 않았다 (Fig. 5B and C).

\section{고 찰}

본 연구에서는 최근 10 여 년 동안 심경부 감염으로 절개배 농술을 받은 환자에서 주로 동정된 균주 및 균주의 항생제 감수성 결과의 변화 양상을 비교·분석하였다.

연구 대상의 성별 분포를 보면 남성이 여성에 비해 많은 수를 차지하고 있었으며, 다른 연구에서와 동일한 결과를 보 였다.3,5) 이는 여성에 비해 남성 흡연자 수가 많은 것과 연관 이 있을 것으로 생각된다. 본 연구에서 여성 환자 중 흡연자의 비율이 $7.9 \%$ 에 비해 남성 환자(55.4\%)의 절반 이상이 흡연자 였다 $(p<0.001)$. Buckley 등 ${ }^{5}$ 은 흡연을 심경부 감염의 위험 인자로 보고하고 있으며, 흡연으로 인해 구강 위생이 불량하 고 잇몸 아래에 세균의 저장소로 작용하는 바이오필름이 형 성되어 숙주가 전신질환에 취약하게 됨으로써 심경부 감염 발병에 영향을 미쳤을 것으로 보인다.)

당뇨는 심경부 감염과 연관된 가장 흔한 전신질환으로 널 리 알려져 있다.)

본 연구에서도 $26.7 \%$ 에 해당하는 환자들이 당뇨에 이환 되어 있었으며, 당뇨에 이환된 환자의 경우 그렇지 않은 환자 
Table 4. Microbiology results of patients with deep neck infections according to involved space

\begin{tabular}{|c|c|c|c|c|}
\hline \multirow[b]{2}{*}{ Organism } & \multicolumn{4}{|c|}{ No. of patients (\%) } \\
\hline & Parapharyngeal & Submandibular & Sublingual space & $\begin{array}{c}\text { Retropharyngeal } \\
\text { space }\end{array}$ \\
\hline No growth bacteria & $20(35.7)$ & $4(14.8)$ & $6(31.6)$ & $5(35.7)$ \\
\hline \multicolumn{5}{|l|}{ Aerobes } \\
\hline \multicolumn{5}{|l|}{ Gram-positve bacteria } \\
\hline Streptococcus viridans & $28(50.0)$ & $12(44.4)$ & $6(31.6)$ & $7(50.0)$ \\
\hline Staphylococcus aureus & $0(0)$ & $4(14.8)$ & $1(5.3)$ & $0(0)$ \\
\hline Streptococcus pyogens & $2(3.6)$ & $1(3.7)$ & $0(0)$ & $0(0)$ \\
\hline Streptococcus, group F & $0(0)$ & $1(3.7)$ & $0(0)$ & $0(0)$ \\
\hline Staphylococcus epidermis & $1(1.8)$ & $0(0)$ & $0(0)$ & $0(0)$ \\
\hline \multicolumn{5}{|l|}{ Gram-negative bacteria } \\
\hline Klebsiella pneumoniae & $4(7.1)$ & $5(18.5)$ & $2(10.5)$ & $3(21.4)$ \\
\hline Escherichia coli & $1(1.8)$ & $0(0)$ & $0(0)$ & $0(0)$ \\
\hline Enterobacter sp. & $1(1.8)$ & $0(0)$ & $1(5.3)$ & $0(0)$ \\
\hline Neisseria sp. & $1(1.8)$ & $0(0)$ & $0(0)$ & $0(0)$ \\
\hline Acinetobacter & $0(0)$ & $0(0)$ & $0(0)$ & $1(7.1)$ \\
\hline \multicolumn{5}{|l|}{ Anaerobes } \\
\hline \multicolumn{5}{|l|}{ Gram-positive bacteria } \\
\hline Peptostreptococcus sp. & $0(0)$ & $1(3.7)$ & $1(5.3)$ & $0(0)$ \\
\hline Lactobacillus & $1(1.8)$ & $0(0)$ & $0(0)$ & $0(0)$ \\
\hline \multicolumn{5}{|l|}{ Gram-negative bacteria } \\
\hline Prevotella sp. & $1(1.8)$ & $2(7.4)$ & $1(5.3)$ & $0(0)$ \\
\hline Citrobacter & $0(0)$ & $0(0)$ & $1(5.3)$ & $0(0)$ \\
\hline
\end{tabular}

sp.: species

에 비해 심경부 감염의 경과가 좋지 않을 확률이 높았다. 당뇨 환자에서 혈당 상승은 부착, 화학주성, 식세포작용 등 여러 중성구 작용을 포함한 숙주 방어 체계를 손상시켜 감염을 쉽 게 유발한다. ${ }^{8}$ 따라서 심경부 감염에 이환된 당뇨 환자들은 수술적, 항생제 치료와 더불어 적절한 혈당 유지가 함께 이루 어져야 한다.

심경부 감염에서는 대부분 복합감염의 양상을 보이며, Streptococcus, $\beta$-hemolytic streptococcus, Staphylococcus, Klebsiella pneumonia 등의 호기성 균주와 Bacteroides, Peptostreptococcus 등의 혐기성 균주가 주로 동정되는 것으 로 보고되고 있다.,10) 본 연구에서는 복합감염은 6예(5\%)로 드물게 나타났으며, 균이 동정되지 않은 경우는 43예(32.8\%) 에 달했는데 이는 입원하기 이전에 1 차 의료기관에서 항생제 를 처방받아 복용한 경우가 많아 세균의 절대 수가 감소했을 것으로 판단된다. 세균배양검사 결과 Streptococcus viridans(35.1\%), Klebsiella pneumonia(13.7\%), Staphylococcus aureus $(4.6 \%)$ 순으로 나타나 이전 연구들과 비슷한 결과를 보였다. ${ }^{3,7-10)}$

가장 흔하게 동정된 Streptococcus viridans는 이질적인 연 쇄구균 집단을 나타내며, 혈액 한천을 용해하여 녹색을 띠게
한다는 의미를 가지고 지어진 이름으로 Streptococcus anginosus, Streptococcus mitis, Streptococcus sanguis, Streptococcus intermedius, Streptococcus constellatus 등을 포 함한다. ${ }^{11)}$ 이는 구강 내에 존재하는 정상 세균총으로 점막 장 벽이 붕괴되는 경우 조직으로 침범하여 농 혹은 농양을 형성 함으로써 심경부 감염을 일으키게 된다. ${ }^{12)}$ 최근 10 년 간 동정 된 균의 변화 양상을 보면 그람 양성 세균과 Streptococcus viridans의 그래프가 유사하게 나타나고 있으며, 이는 Streptococcus viridans 가 심경부 감염의 주요 원인을 차지하고 있다는 선행 연구와도 일치하는 결과이다. ${ }^{37-10)}$ 또한 본 연구 결과 최근 Streptococcus viridans의 동정률이 높아지고 있 다는 점이 확인되어 Streptococcus viridans에 감수성이 있 는 항생제를 경험적 항생제로 선택하는 것이 중요하다고 판 단된다.

다음으로 흔하게 동정된 Klebsiella pneumoniae의 경우 이 전 연구들에서 당뇨 환자에서 당뇨에 이환되지 않은 환자에 비해 동정률이 높게 나온 것으로 알려져 있다. ${ }^{1,7,13,14)}$ 본 연구 에서도 당뇨 환자에서의 Klebsiella pneumoniae 동정률이 3.364배 높은 것으로 확인되었다. 선행 연구에서와 유사하게 본 연구에서도 Klebsiella pneumoniae의 ampicillin 내성이 
Korean J Otorhinolaryngol-Head Neck Surg I 2021;64(5):327-35

Table 5. Microbiology results of patients with deep neck infections according to lifestyle habits

\begin{tabular}{|c|c|c|c|c|c|c|c|}
\hline \multirow{3}{*}{ Organism } & \multicolumn{7}{|c|}{ No. of patients (\%) } \\
\hline & \multirow{2}{*}{ Total } & \multicolumn{3}{|c|}{ Smoking } & \multicolumn{3}{|c|}{ Drinking } \\
\hline & & Smoking & Non-smoking & $p$-value & Alcohol & Non-alcohol & $p$-value \\
\hline No growth bacteria & $46(35.1)$ & $14(25.9)$ & $32(41.6)$ & 0.065 & $8(21.6)$ & $38(40.4)$ & 0.042 \\
\hline \multicolumn{8}{|l|}{ Aerobes } \\
\hline \multicolumn{8}{|l|}{ Gram-positve bacteria } \\
\hline Streptococcus viridans & $46(35.1)$ & $23(42.6)$ & $23(29.9)$ & 0.133 & $15(40.5)$ & $31(33.0)$ & 0.414 \\
\hline Staphylococcus aureus & $6(4.6)$ & $1(1.9)$ & $5(6.5)$ & 0.400 & $1(2.7)$ & $5(5.3)$ & 1.000 \\
\hline Streptococcus pyogens & $5(3.8)$ & $3(5.6)$ & $2(2.6)$ & 0.403 & $1(2.7)$ & $4(4.3)$ & 1.000 \\
\hline Streptococcus, group F & $1(0.8)$ & $0(0)$ & $1(1.3)$ & 1.000 & $0(0)$ & $1(1.1)$ & 1.000 \\
\hline Staphylococcus epidermis & $1(0.8)$ & $1(1.9)$ & $0(0)$ & 0.412 & $1(2.7)$ & $0(0)$ & 0.282 \\
\hline \multicolumn{8}{|l|}{ Gram-negative bacteria } \\
\hline Klebsiella pneumoniae & $18(13.7)$ & $9(16.7)$ & $9(11.7)$ & 0.415 & $7(18.9)$ & $11(11.7)$ & 0.280 \\
\hline Escherichia coli & $3(2.3)$ & $3(5.6)$ & $0(0)$ & 0.068 & $3(8.1)$ & $0(0)$ & 0.021 \\
\hline Enterobacter sp. & $2(1.5)$ & $1(1.9)$ & $1(1.3)$ & 1.000 & $0(0)$ & $2(2.1)$ & 1.000 \\
\hline Neisseria sp. & $1(0.8)$ & $0(0)$ & $1(1.3)$ & 1.000 & $0(0)$ & $1(1.1)$ & 1.000 \\
\hline Acinetobacter & $1(0.8)$ & $1(1.9)$ & $0(0)$ & 0.412 & $0(0)$ & $1(1.1)$ & 1.000 \\
\hline \multicolumn{8}{|l|}{ Anaerobes } \\
\hline \multicolumn{8}{|l|}{ Gram-positive bacteria } \\
\hline Peptostreptococcus sp. & $4(3.1)$ & $1(1.9)$ & $3(3.9)$ & 0.643 & $1(2.7)$ & $3(3.2)$ & 1.000 \\
\hline Lactobacillus & $1(0.8)$ & $0(0)$ & $1(1.3)$ & 1.000 & $0(0)$ & $1(1.1)$ & 1.000 \\
\hline \multicolumn{8}{|l|}{ Gram-negative bacteria } \\
\hline Prevotella sp. & $3(2.3)$ & $1(1.9)$ & $2(2.6)$ & 1.000 & $1(2.7)$ & $2(2.1)$ & 1.000 \\
\hline Citrobacter & $1(0.8)$ & $1(1.9)$ & $0(0)$ & 0.412 & $1(2.7)$ & $0(0)$ & 0.282 \\
\hline
\end{tabular}

sp.: species

Table 6. Microbiology results of patients with deep neck infections with and without diabetic mellitus

\begin{tabular}{|c|c|c|c|c|}
\hline \multirow{2}{*}{ Organism } & \multicolumn{4}{|c|}{ No. of patients (\%) } \\
\hline & Total & $\mathrm{DM}$ & Non-DM & $p$-value \\
\hline No growth bacteria & $46(35.1)$ & $9(25.7)$ & $37(38.5)$ & 0.174 \\
\hline \multicolumn{5}{|l|}{ Aerobes } \\
\hline \multicolumn{5}{|l|}{ Gram-positve bacteria } \\
\hline Streptococcus viridans & $46(35.1)$ & $12(34.3)$ & $34(35.4)$ & 0.904 \\
\hline Staphylococcus aureus & $6(4.6)$ & $1(2.9)$ & $5(5.2)$ & 1.000 \\
\hline Streptococcus pyogens & $5(3.8)$ & $0(0)$ & $5(5.2)$ & 0.324 \\
\hline Streptococcus, group F & $1(0.8)$ & $1(2.9)$ & $0(0)$ & 0.267 \\
\hline Staphylococcus epidermis & $1(0.8)$ & $0(0)$ & $1(1.0)$ & 1.000 \\
\hline \multicolumn{5}{|l|}{ Gram-negative bacteria } \\
\hline Klebsiella pneumoniae & $18(13.7)$ & $9(25.7)$ & $9(9.4)$ & 0.023 \\
\hline Escherichia coli & $3(2.3)$ & $2(5.7)$ & $1(1.0)$ & 0.174 \\
\hline Enterobacter sp. & $2(1.5)$ & $0(0)$ & $2(2.1)$ & 1.000 \\
\hline Neisseria sp. & $1(0.8)$ & $0(0)$ & $1(1.0)$ & 1.000 \\
\hline Acinetobacter & $1(0.8)$ & $0(0)$ & $1(1.0)$ & 1.000 \\
\hline \multicolumn{5}{|l|}{ Anaerobes } \\
\hline \multicolumn{5}{|l|}{ Gram-positive bacteria } \\
\hline Peptostreptococcus sp. & $4(3.1)$ & $0(0)$ & $4(4.2)$ & 0.573 \\
\hline Lactobacillus & $1(0.8)$ & $0(0)$ & $1(1.0)$ & 1.000 \\
\hline \multicolumn{5}{|l|}{ Gram-negative bacteria } \\
\hline Prevotella sp. & $3(2.3)$ & $1(2.9)$ & $2(2.1)$ & 1.000 \\
\hline Citrobacter & $1(0.8)$ & $0(0)$ & $1(1.0)$ & 1.000 \\
\hline
\end{tabular}

DM: diabetes mellitus, sp.: species 

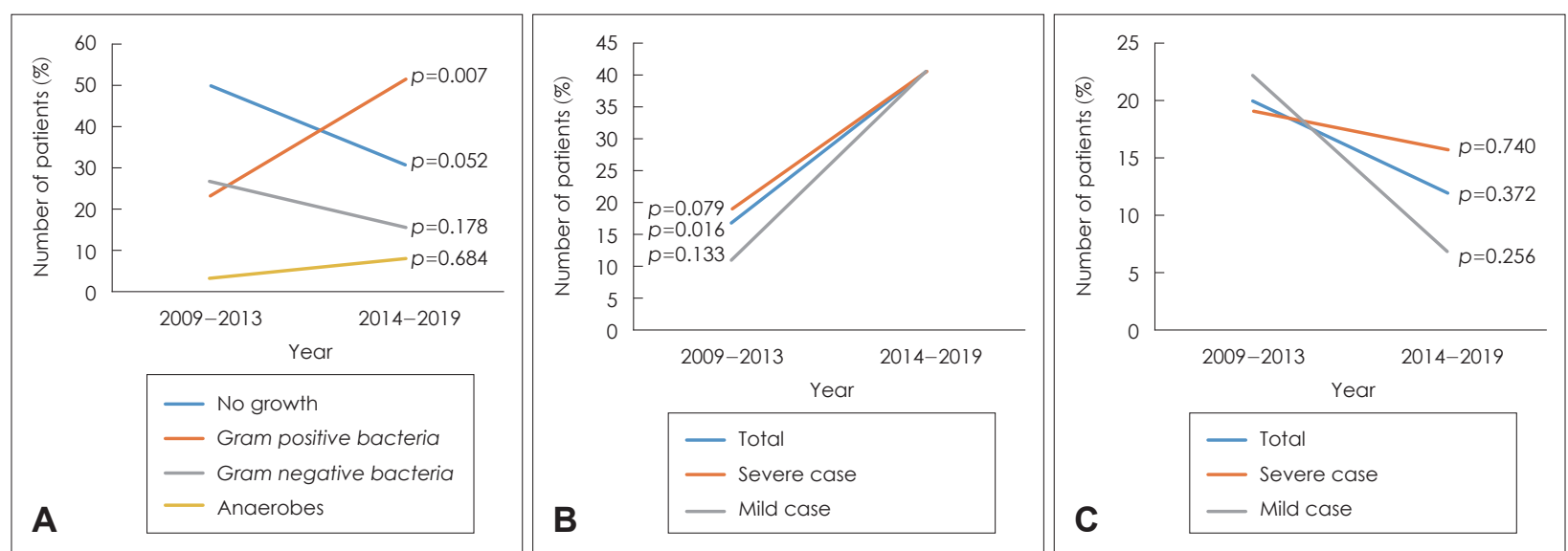

Fig. 2. Isolation rate of different types of bacteria (A), Streptococcus viridans (B) and Klebsiella pneumonia (C) during each 5 year interval. The isolation rates of gram positive bacteria $(p=0.007)$ was increased significantly between 2009 and 2019 . The isolation of anaerobes $(p=0.684)$ was increased and that of gram negative bacteria $(p=0.178)$ was decreased, but they were not statistically significant. The identification of Streptococcus viridans $(p=0.016)$ increased in the recent 10 years with statistical significance. The identification of Klebsiella pneumoniae $(p=0.372)$ was shown to decrease in recent years, but it was not statistically significant.

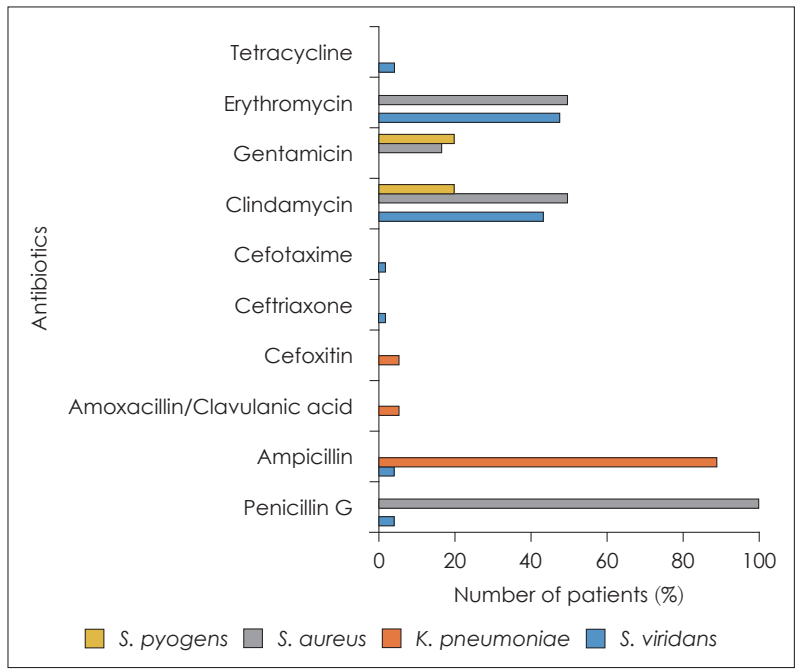

Fig. 3. Results of antibiotic susceptibility test among mainly isolated bacteria. The isolation rates of clindamycin and erythromycin -resistant S. viridans were respectively $43.4 \%, 47.8 \%$, but Streptococcus was sensitive to ampicillin and ceftriaxone. All cases except 2 cases with $K$. pneumonia isolated were resistant to ampicillin and half of them were resistant to clindamycin and erythromycin. S. pyogens: Streptococcus pyogens, S. aureus: Staphylococcus aureus, K. pneumoniae: Klebsiella pneumoniae, S. viridans: Streptococcus viridans.

88.9\%로 높게 나타났다. ${ }^{13)}$ 따라서 심경부 감염에 이환된 당뇨 환자들의 경우 ampicillin 단독요법을 사용하는 것은 피해야 한다.

전체 혐기성 세균의 동정률 자체는 낮으나 2018년 Tsai 등 ${ }^{15)}$ 이 발표한 논문에서 편도 주위 농양에서 혐기성 세균의 동정 률이 증가하는 것과 유사하게 본 연구에서도 심경부 감염의 혐기성 세균의 동정률이 최근 증가하고 있는 양상을 보이고 있다. 따라서 혐기성 세균에도 효과가 있는 항생제를 함께 사 용하는 것이 심경부 감염 치료에 도움이 될 것이다. 혐기성

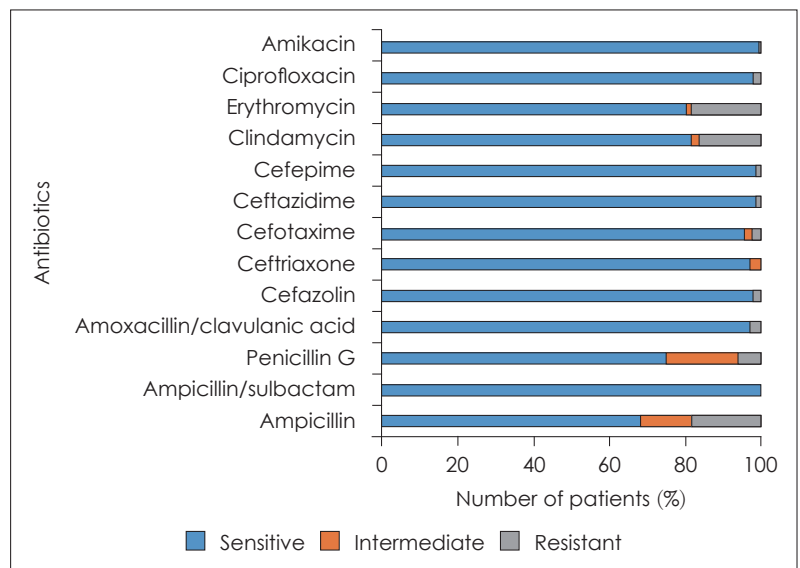

Fig. 4. Relative efficacy of different antibiotics against all microbes. Ampicillin, erythromycin and clindamycin were relatively resistant against all microbes. On the other hand, ampicillin/sulbactam and cephalosporin were relatively sensitive to all microbes.

세균의 전체 동정률이 낮은 원인에는 적절한 혐기성 세균의 채취 및 수송이 이루어지지 않았을 가능성에 대해서 생각해 볼 수 있다. 혐기성 세균의 배양을 위해서 검체는 공기에 노 출되지 않도록 하고 혐기성 세균 수송배지에 넣어 즉시 검사 실로 수송하여야 한다. ${ }^{16)}$ 그러나 절개 배농 시 나온 농은 공 기에 이미 노출된 상태에서 채취되었을 가능성이 높으며, 평 일 저녁이나 공휴일에 채취된 검체는 평일 정규시간이 되어야 검사실로 수송 및 배양이 시작되기 때문에 혐기성 세균이 실 제보다 덜 배양될 가능성이 있다.

소아에서는 성인과 심경부 감염의 원인균에 차이가 있는 것으로 알려져 있다. 본 연구에서도 Streptococcus viridans 가 가장 흔하게 동정된 성인과 달리 소아 심경부 감염 환자에 서의 세균배양검사 결과 Staphylococcus aureus의 동정률이 가장 많았으며, 이전 연구 결과들에서와 일치한다. ${ }^{1718)}$ 소아 


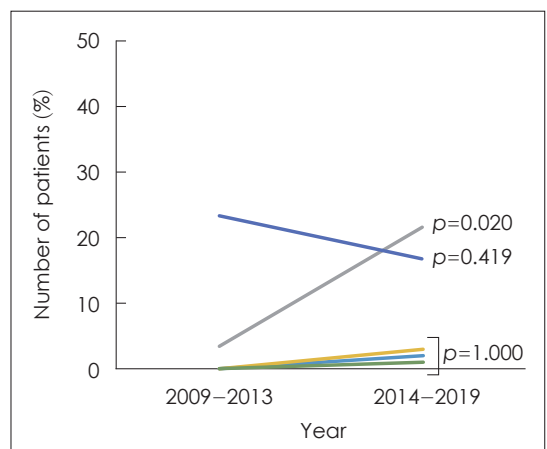

- 2nd generation cephalosporin
A
Ard generation cephalosporin
Clindamycin
- Amoxicillin/clavulanic acid
- Ampicillin
Ampicillin/sulbactam
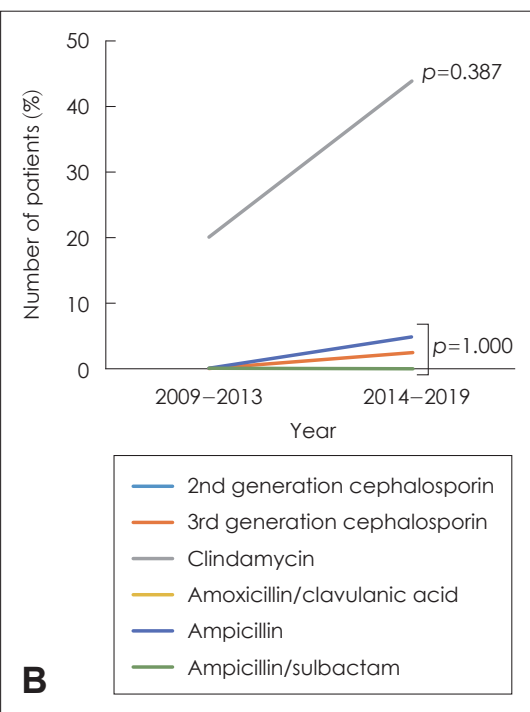

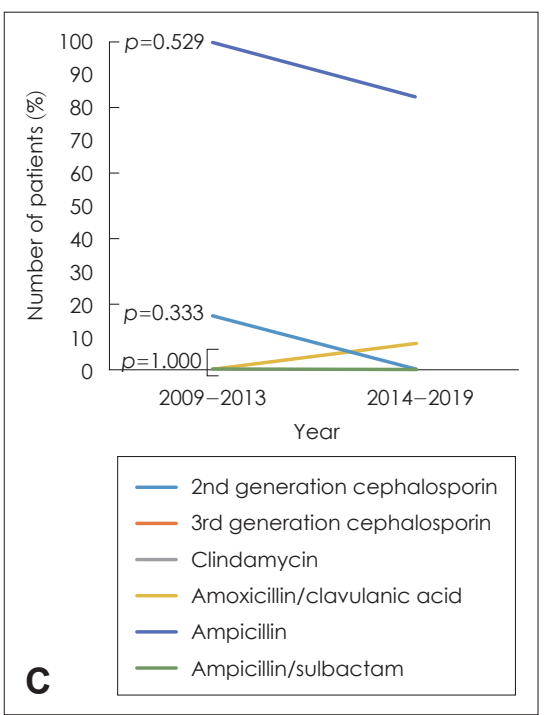

Fig. 5. Changing trends of antibiotic resistance against all isolated microbes (A), Streptococcus viridans (B) and Klebsiella pneumonia (C) during 10 years. The identification of clindamycin-resistant pathogens was increased with statistically significance $(p=0.020)$, but the change of the isolation of other antibiotics-resistant pathogens were statistically insignificant. The isolation rate of Streptococcus viridans and Klebsiella pneumonia which were resistant to all antibiotics, also changed with statistical insignificance.

에서 동정된 Staphlococcus aureus 전체에서 penicillin에 대 해, $75 \%$ 에서 clindamycin에 대해 저항성이 있는 것을 확인 되었으며, 소아 심경부 감염 환자에서 항생제 사용하는 경우 penicillin 및 clindamycin 단독요법은 피하는 것이 좋다. 소 아 심경부 감염의 원인균은 연령과 침범 부위에 따라 다르다. 1세 이하에서는 Staphylococcus aureus, 1세 이상에서는 Streptococcus pyogens의 동정률이 높으며, Brook 등에 따 르면 악하공간은 Staphylococcus aureus, 인두곁공간 및 인 두뒤공간에는 Streptococcus pyogens과 관련되어 있다고 보고하였다. ${ }^{19,20)}$

항생제 치료의 발달과 구강 위생의 향상으로 심경부 감염 의 발병률이 감소하고 있다는 보고들이 있으나 본 연구에서 매년 심경부 감염으로 입원 치료를 받은 환자 수는 오히려 연구 초보다 연구 후반에 증가한 양상을 보이고 있다.1,313) 심 경부 감염의 심각한 합병증을 예방하기 위해서 적절한 경험 적 항생제를 선택하여 치료하는 것이 중요하다. ${ }^{5,17)} 10$ 여 년 동 안 비율에는 차이가 있으나 Streptococcus viridians, Klebsiella pneumoniae가 심경부 감염에서 주로 동정된 균이라 는 점으로 볼 때 이에 항균력 있는 항생제를 선택해야 한다. 이에 더하여 비록 본 연구에서 혐기성 세균의 동정률이 낮게 나왔으나 혐기성 세균의 배양의 어려움이 있고 심경부 감염 이 대부분 복합감염 양상을 띤다는 이전 연구 결과를 고려 해볼 때 혐기성 세균에 항균력을 가지는 항생제를 함께 사용 하는 것이 필요하다. 본 연구에서는 심경부 감염 입원 환자 의 경험적 항생제로 2 세대 혹은 3 세대 cephalosporin 계열 항생제에 혐기성 세균에 항균력을 가지는 clindamycin을 포
함하여 사용하였으며, 이를 경험적 항생제로 사용하는 것이 적절하였다고 판단된다. 또한 항생제 내성균의 발현을 고려 하였을 때 심경부 감염의 주된 원인균과 혐기성 세균에 두루 항균력이 뛰어난 ampicillin/sulbactam 및 amoxicillin/clavulanic acid 역시 나이 및 기저질환에 관계없이 심경부 감염 의 경험적 항생제로 훌륭한 선택이라고 여겨진다.

\section{Acknowledgments}

None.

\section{Author Contribution}

Conceptualization: Soo Yeon Jung. Data curation: Ju Hyun Yun. Formal analysis: Ju Hyun Yun. Investigation: Ju Hyun Yun, Soo Jin Kim. Methodology: Soo Yeon Jung, Ju Hyun Yun. Resources: Soo Yeon Jung, Han Su Kim. Supervision: Soo Yeon Jung. Validation: Ju Hyun Yun. Writing — original draft: Ju Hyun Yun. Writing-review \& editing: Soo Yeon Jung.

\section{ORCID}

Soo Yeon Jung ～https://orcid.org/0000-0001-7497-3057

\section{REFERENCES}

1) Brito TP, Hazboun IM, Fernandes FL, Bento LR, Zappelini CEM, Chone CT, et al. Deep neck abscesses: Study of 101 cases. Braz J Otorhinolaryngol 2017;83(3):341-8.

2) Sethi DS, Stanley RE. Deep neck abscesses--changing trends. J Laryngol Otol 1994;108(2):138-43.

3) Kim YS, Park JH, Chun SS, Han DY, Kim JE, Lee BD. Clinical analysis of deep neck infection. Korean J Otorhinolaryngol-Head Neck Surg 2010;53(10):627-31.

4) Boscolo-Rizzo P, Stellin M, Muzzi E, Mantovani M, Fuson R, Lupato V, et al. Deep neck infections: A study of 365 cases highlighting recommendations for management and treatment. Eur Arch Otorhinolaryngol 2012;269(4):1241-9. 
5) Buckley J, Harris AS, Addams-Williams J. Ten years of deep neck space abscesses. J Laryngol Otol 2019;133(4):324-8.

6) Sharma K, Das D, Joshi M, Barman D, Sarma AJ. Deep neck space infections-a study in diabetic population in a tertiary care centre. Indian J Otolaryngol Head Neck Surg 2018;70(1):22-7.

7) Huang TT, Tseng FY, Yeh TH, Hsu CJ, Chen YS. Factors affecting the bacteriology of deep neck infection: A retrospective study of 128 patients. Acta Otolaryngol 2006;126(4):396-401.

8) Yang W, Hu L, Wang Z, Nie G, Li X, Lin D, et al. Deep neck infection: A review of 130 cases in Southern China. Medicine (Baltimore) 2015;94(27):e994.

9) Yang SW, Lee MH, See LC, Huang SH, Chen TM, Chen TA. Deep neck abscess: An analysis of microbial etiology and the effectiveness of antibiotics. Infect Drug Resist 2008;1:1-8.

10) Cordesmeyer R, Kauffmann P, Markus T, Sömmer C, Eiffert H, Bremmer F, et al. Bacterial and histopathological findings in deep head and neck infections: A retrospective analysis. Oral Surg Oral Med Oral Pathol Oral Radiol 2017;124(1):11-5.

11) Coykendall AL. Classification and identification of the viridans streptococci. Clin Microbiol Rev 1989;2(3):315-28.

12) Han JK, Kerschner JE. Streptococcus milleri: An organism for head and neck infections and abscess. Arch Otolaryngol Head Neck Surg 2001;127(6):650-4.
13) Kim DH, Choi HG, Kim JH, Kim HS, Park B. Characteristics of microbiology of deep neck abscess. Korean J OtorhinolaryngolHead Neck Surg 2014;57(6):379-83.

14) Celakovsky P, Kalfert D, Smatanova K, Tucek L, Cermakova E, Mejzlik J, et al. Bacteriology of deep neck infections: Analysis of 634 patients. Aust Dent J 2015;60(2):212-5.

15) Tsai YW, Liu YH, Su HH. Bacteriology of peritonsillar abscess: The changing trend and predisposing factors. Braz J Otorhinolaryngol 2018;84(5):532-9.

16) Brook I. Anaerobic bacteria in upper respiratory tract and other head and neck infections. Ann Otol Rhinol Laryngol 2002;111(5 Pt 1): 430-40.

17) Lee DW, Lee HS, Lee KY, Park IB, Park CW, Tae K. A clinical study of deep neck infection in children. Korean J Otolyarngol 2005;48(11):1382-7.

18) Mungul S, Maharaj S. Microbiology of paediatric deep neck space infection. Int J Pediatr Otorhinolaryngol 2019;123:116-22

19) Coticchia JM, Getnick GS, Yun RD, Arnold JE. Age-, site-, and time-specific differences in pediatric deep neck abscesses. Arch Otolaryngol Head Neck Surg 2004;130(2):201-7.

20) Brook I. Microbiology of abscesses of the head and neck in children. Ann Otol Rhinol Laryngol 1987;96(4):429-33. 